\title{
ARANY OKLEVELES PSZICHOLÓGUSOK
}

Az ELTE PPK Kari Tanácsa 2018. október 17-én arany oklevelet adományozott az 50 éve pszichológia szakot végzett jubileumi ünnepeltek részére. A jubileumi oklevelek adományozása alkalmából az ELTE Ünnepi Közgyúlésén elhangzott prof. Dúll Andrea, az ELTE Pedagógiai és Pszichológiai Karának általános dékánhelyettese ünnepi beszéde.

Az oklevelet hét pszichológus vehette át: Dr. Bagdy Emôke, Dr. Haraszti Gyuláné Kiss Eszter, Dr. Juhász Erzsébet, Dr. Kalmár Magdolna, Dr. Nagy Attila, Sulyok Tamás József és Dr. Szombathelyi Éva.

Tisztelt Ünnepi Közgyúlés, tisztelt Rektor Úr, tisztelt Jubilálók, kedves Vendégek! Tisztelettel és szeretettel köszöntöm a jubileumi diplomásokat!

Nagy öröm és megtiszteltetés számomra, hogy a kedves kollégákat a Pedagógiai és Pszichológiai Kar képviseletében én köszönthetem. Néhányukban tanáraimat, volt fơnökömet és jelenlegi kollégámat is tisztelhetem.

Az évfordulók remek alkalmakat jelentenek arra, hogy elgondolkodjunk az eltelt éveken. Az elmúlt 50 év nemcsak a ma arany oklevelüket átvevô kedves kollégák számára, személyes életútjuk nézôpontjából fontos, hanem a pszichológia egésze szempontjából is.

Nem könnyú 50 évet áttekinteni - nem csak a most rendelkezésemre álló idô rövidsége miatt, hanem már csak azért sem, mert pszichológusként három évtizede magam is részese, átélője vagyok a pszichológia alakulásának, fejlődésének. A ma arany oklevelüket átvevôk szakmai pályája teljes mértékben átíveli ezt az ötven évet, amelyet sok tekintetben a pszichológia hôskorának tekintünk, magyarországi vonatkozásban mindenképp.

A nagy társadalmi átalakulások közepette hol simább szakaszokban, hol nagy kavarodások által kísérve eleinte tanulták, majd múvelték a pszichológiát, amely az elmúlt 50 évben nem csak itthon, de az egész világon újjászületett.

A pszichológia és maga a pszichológus hivatás fokozatosan alakult ki a 20. század során (Pléh, 2008). A legtöbb országban (nálunk is) háromféle szerep - filozófus és természettudós, üzletember és biológus, orvos és filozófus - szerepegyeztetéséból, szerephibridizációjából (Pléh, 2003) született. Hosszú időn keresztül elsôsorban akadémikus diszciplína volt, ugyanakkor kezdettôl hangsúlyozta az emberek jóllétének fontosságát: a pszichológia „a boldogságot az emberek jogos céljának tartja, és viszony- 


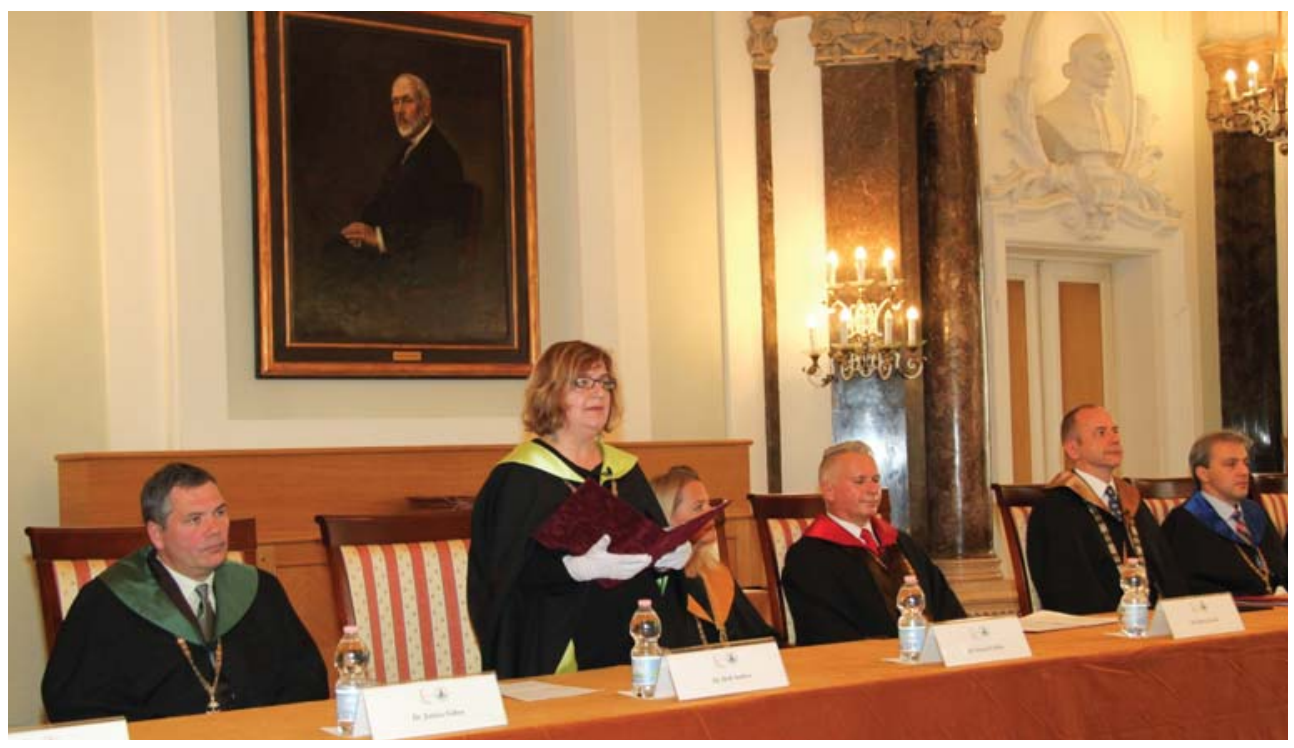

A képen látható (balról jobbra): Dr. Juhász Gábor TáTK dékán, Dr. Dúll Andrea PPK általános dékánhelyettes, Dr. Somssich Réka ÁJK oktatási dékánhelyettes, Dr. Borhy László rektor,

Dr. Sonkoly Gábor BTK dékán, Dr. Kozsik Tamás egyetemi docens, IK tudományos és innovációs ügyek dékánhelyettese

lagos megnyomorított körülményeik között is a boldogság növelését tartja támogatandónak" (Pléh, 2008, 391). Ez a törekvés az arany okleveles kollégák személyes életútjában is jellemzố. Maga a pszichológia és a pszichológus szakma sorsa egyáltalán nem a töretlen boldogságnövekedéssel jellemezhetô, Pléh Csaba szavaival inkább egy „hôsies múlt"-ból (Pléh, 2016, 701) és annak során alakult ki. Hogy ezt érzékeltessem, engedjenek meg egy mozaikszerú áttekintést a magyar pszichológia elmúlt 50 évérôl.

A pszichológus szakma tanszékei, a „pszichológiai részlegek az egyetemi világban többnyire a filozófia valamilyen tagozatai voltak, s csak a második világháború után jelent meg az akadémikus önállósulás. Európa keleti részén, így Magyarországon is ezt a folyamatot sok ideológiai és társadalmi alapú megtorpanás kísérte. Az embert önmagában tekintố, s viszonylag stabil paraméterekkel tudományosan vizsgálhatónak tartó pszichológia sokféle rendteremtố és gyors változást hirdetố mozgalom számára gyanús" (Pléh, 2008, 556).

A pszichológia hányatott sorsát, ugyanakkor újra- meg újramegújulási képességét jelzi, hogy Budapesten az 1912-ben alapított Fôvárosi Pedagógiai Szemináriumnak kezdettôl volt pedagógiai-lélektani laboratóriuma, amit az a Révész Géza vezetett, akinek életrajzában fontos idôszak „1918-19. Tanszék s egyetem szervezése forradalmak közepette" (Pléh, 2009a, 76). Összességében, az ELTE-n 100 éves a pszichológia oktatása: 1918 októberében bízták meg Révészt a Budapesti Tudományegyetemen (a késốbbi ELTE-n) kísérleti lélektani tanszék szervezésével: „A Császári és Apostoli Királyi Felsége [...] legkegyelmesebben megengedni méltóztatott, hogy a budapesti tudományegyetemen a kísérleti lélektan számára a költségvetésileg rendelkezésre álló eló-

Bocsánat, de oldalpárban a két képnek együtt kell

futnia, ha fölé teszek 6 sort, az nagyon csúnya 


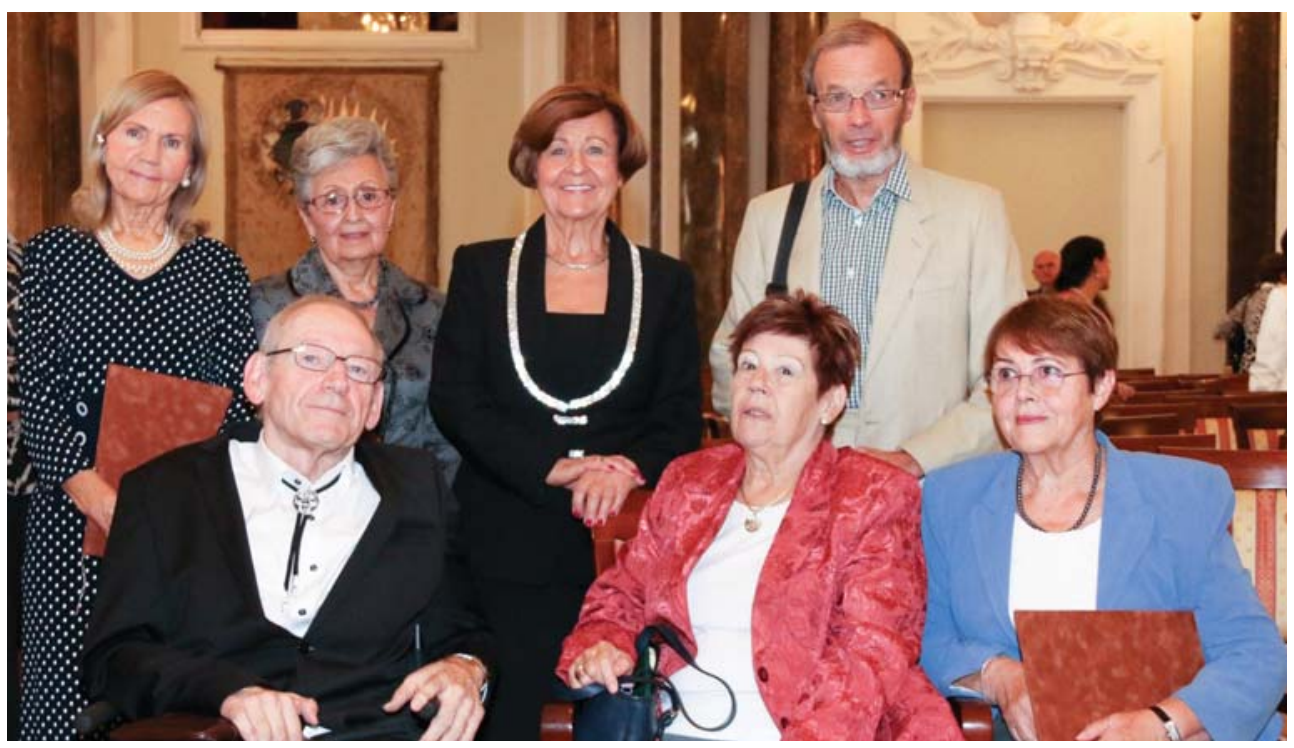

A képen látható ünnepeltek és ünneplôk: balról jobbra felsố sor: Dr. Takó Emôke, Varga Zsuzsa, Dr. Bagdy Emốke, Helmich Dezsô;

balról jobbra alsó sor: Dr. Nagy Attila, Dr. Juhász Erzsébet, Dr. Császár Ildikó

adói tiszteletdíj felhasználásával rendkívüli tanszék szerveztessék” (Pléh, 2009a, 77). Igaz, hogy „Révészt [gyakorlatilag azonnal - beszúrás DA] felfüggesztik állásából azon hamis vád alapján, hogy nem volt hajlandó magát alávetni a filozófiai fakultás igazságszolgáltatásának” (Pléh, 2009b, 473). Azonban „Révész nem egykönnyen adta meg magát. Hosszan érvelt az empirikus munkát képviselő 'lélektani intézet' megtartása mellett az új miniszternek írott beadványában” (Pléh, 2009b, 477). „Révész személyét és intézetét egyaránt támadások érték, minek következtében ô rövidesen külföldre távozott, és az „egyetemi gyermeklélektan tanítás jó idôre ellehetetlenült” (Donáth, 2007, 51). A Budapesti Egyetemen végül 1947-ben alakult meg egy tartósan múködô Lélektani Tanszék, de a valódi pszichológusképzés csak 1963-ban kezdődhetett el (Pléh, 2003).

Pléh Csaba szerint a pszichológia újramegjelenése a magyar tudományos életben 1960-70 közé tehetô, ez „az újjászületés kora” (Pléh, 2016, 703), amikor „a Kádár-korszak konszolidációjának szerény részeként megjelenik itthon az akadémikus és az alkalmazott pszichológia” (Pléh, 2016, 701). Ennek a képzésnek voltak részesei a tisztelt jubileumi diplomások. Ebben a „hôsies” fejlődésben a pszichológia elsôdleges érdeklōdési területévé váltak egyrészt az egészségügy, másrészt a társadalmi problémák (Pléh, 2008). Ennek a folyamatnak a lényege részben az volt, hogy a pszichológia eltávolodott az orvosi területektôl, például elkülönült a pszichiáter és a pszichológus munkája (Pléh, 2008), majd fokozatosan megtalálta helyét a pedagógiával való viszonylatában is (Pléh, 2010). A 70-es évek Mérei Ferenc szavaival „egy fölfutó időszak volt” (idézi Borgos, 2006, 18-19). 
Az elmúlt ötven év egésze hôsies korszaknak tekinthetô - akik itt most jelen vannak, jól tudják, mert átélték. A gyógyítás sok tekintetben hôsies hozzáállást, megnyilvánulásokat kíván a mindennapi emberi szinten, hiszen a pszichológus önmagával, személyiségével gyógyít, életminôséget javít - ehhez, a szakmai hozzáértés és elkötelezettség mellett nyilvánvalóan nagy énerô is szükséges, aminek a kialakulását és fenntartását az ebben a korszakban kialakult szakmai csoportok is támogatták. Jellemzôen ezek a szakmai csoportok szinte életközösséggé is formálódtak. Mérei Ferenc szavaival: „A közösség keresésének és a személyiség hangsúlyának összeegyeztetési igénye állandó feladat [...]. [Ennek - beszúrás DA] hatékony útja valószínúleg a társas szerzôdés, [...] a másik megértése, a többiekhez való igazodás, empátia és megegyezés, alkudozás és kompromisszum. Lényege a biztonságtudat, az a tudat, hogy akivel kötöttem, az betartja, illetve azok, akikkel megegyeztem, tiszteletben tartják a szerzódést. Ez védheti meg az embert legbiztosabban a nehéz helyzetekben is” (idézi Bagdy, 1985, 247-248).

„Pár tucat ember múvelte valahogyan (értve ezen, hogy szúkös keretekben) az ekkoriban gyakran lenézett vagy lesajnált pszichológiát” (Pléh, 2016, 703). Nem volt könnyú a gyógyító realitást képviselni „sem a pártpropaganda optimista betegségpolitikájával szemben”, sem a „nagypszichiátra” (mindkét idézet: Pléh, 2016, 703) kemény, gyógyszeres kezelést középpontba állító betegség- és gyógyításfogalmával szemben. A klinikai, gyógyító felnôtt- és gyermekpszichológusok fôleg a legendás Mérei Ferenc körül kialakult sodró közegben éltek. „Mérei rendkívül kitárulkozó, nagyon informális, ugyanakkor expanzív” (Pléh, 2016, 704), „szuggesztív, öntörvényú és másokat is erre inspiráló személyiség” (Borgos, 2006, 25), gyakran szubjektívan megnyilvánuló szakember volt, „beállítódásának crédója: nem várni, nem hagyni-megtörténni, hanem aktívan keresni, elébe menni, és - fóképpen - megtalálni és kiaknázni beloole a kellemest, az örömöt” (K. Horváth, 2005, 114). „A Mérei köré szerveződött csoportok létrejötte és múködése elválaszthatatlan az adott korszaktól, a társadalmi-politikai és szellemi kontextustól” (Borgos, 2006, 19) - és természetesen közvetve vagy közvetlenül, ünnepeltjeink személyes életétôl. A Mérei-csoport hatása ma is érzôdik a szakmában.

„Emberi kiállást kívánt a kísérleti pszichológia múvelése [...] is” (Pléh, 2016, 703). Ennek alakulásában kulcsszerepe volt Kardos Lajosnak, aki így jellemezte önmagát: „Azt hiszem, nagyon is szemlélôdô vagyok. Nem vagyok igazán erélyesen cselekvô” (Pléh, 1985, 350). Kardos „nem volt robusztus egyéniség, aki érzelemgerjesztő és lenyűgözô eréllyel teremt maga körül mesternek kijáró atmoszférát. Ennek ellenére, vagy éppen ezért, vitathatatlan tudományos és emberi hatékonysága, az ôt övezô tiszteletteljes és szeretetteljes légkör, amelynek kialakulásában idôtálló tudomány-ethosza és kristályosan tiszta gondolatvezetése, kifinomult modora és modorosságtól mentes egyéni »charme«-ja mind közrejátszott” (Hunyady, 1985, 374).

A következó évtized lényegi folyamatait (1970-80) a társadalmi individuáció mellett a pszichológia terjedése és az egyre specializálódó szakmai kompetenciák kialakulása jelentette (Pléh, 2016).

1980-90 között lezajlott a pszichológia társadalmi szintû elfogadása, párhuzamosan az „ideológiai ellenôrzés gyengülésé”-vel és a „létezô szocializmus kibontakozó válságá”-val (Pléh, 2016, 701).

1990-2010 között pedig ,az igazi felfutás korszaka” zajlott, sajnos, egyúttal szembeállítva „a pszichológiai szociális ellátórendszer visszaszorulásával” (Pléh, 2016, 701). 
Ez a nagyon rövid, mozaikos áttekintés talán láttatni engedte, hogy milyen nagyívú folyamat játszódott le a hazai pszichológia elmúlt 50 évében. Mindazoknak, akik részt vettek a pszichológia újraalakulásának 50 éves folyamatában és munkájukkal aktívan újrateremtették ezt a szakterületet, köszönettel tartozunk.

Kedves Arany Okleveles Kollégák!

Ma a pszichológiatudomány népszerú, elismert - ugyanakkor sokak szerint válságon, de legalábbis „átalakuláson megy keresztül és új utakat nyit meg” (Szokolszky, 2018, 590). „A vizsgálódások és kétségek egyfajta bizalmi válság megfogalmazódásához vezettek az empirikus kutatások egy részének érvényességével és megbízhatóságával kapcsolatban” (Szokolszky, 2018, 568), gyakorlati oldalról pedig a pszichológia - tudományos tekintélye ellenére - sok tekintetben épp a trivializálódás, az „eltréningpiacosodás” irányába halad. Kiemelten fontos feladatunk egyik oldalon „a megfelelő tudományos kultúra kialakítása és fenntartása” (Szokolszky, 2018, 590), a másik oldalon az aurahegesztôk, az életörömkovácsok „tanaival” szemben a pszichológia elhivatott szakmaiságának megôrzése.

A pszichológiának ebben a legújabb, komoly kihívásokat tartalmazó korszakában is számítunk az Önök értô és bölcs közremúködésére. További életpályájukhoz jó egészséget, sok boldogságot, pszichológiai növekedést kívánok személyes és szakmai területen egyaránt!

\section{IRODALOM}

Bagdy, E. (Ed) (1985). A szabadság elsô pontja: szeretni az életet. Beszélgetés a 75 éves Mérei Ferenccel. Magyar Pszichológiai Szemle, 42(3), 241-253.

Borgos, A. (2006). „Egy mutatvány forgatókönyve”. Motívumok Mérei Ferenc pályájából és személyiségébôl, nyilatkozatai és tanítványai tükrében. In A. Borgos, F. Erôs, \& Gy. Litván (Eds), Mérei élet-mú (pp. 11-34). Budapest: Új Mandátum Kiadó.

Donáth, P. (2007). Adalékok Nagy László pályájához. Budapest: Trezor Kiadó.

K. Horváth, Zs. (2005). A lélek segédigéi. A munkaszolgálat tapasztalata és elaborációja: Mérei Ferenc. Korall, 21-22, 97-123.

Hunyady, Gy. (1985). Kardos Lajos (1899-1985). Magyar Pszichológiai Szemle, 42(5), 373-375.

Pléh, Cs. (Ed) (1985). Élmények, barátok, örömök. Interjú a 85 éves Kardos Lajossal. Magyar Pszichológiai Szemle, 42(4), 345-361.

Pléh, Cs. (2003). A természet és a lélek. Budapest: Osiris Kiadó.

Pléh, Cs. (2008). A pszichológia örök témái: történeti bevezetés a pszichológiába. Budapest: Typotex Kiadó.

Pléh, Cs. (2009a). Révész Géza - A sors feszültségei levelezése és székfoglalója tükrében. Thalassa, 20(4), 75-100.

Pléh, Cs. (2009b). A korai magyar kísérleti pszichológia és a nagyvilág. Révész Géza emlékére. Magyar Pszichológiai Szemle, 64(3), 467-495.

Pléh, Cs. (2010). A lélektan története. Budapest: Osiris Kiadó.

Pléh, Cs. (2016). Intézmények, eszmék és sorsok a magyar pszichológia fél évszázadában 1960-2010. Magyar Pszichológiai Szemle, 71(4/5), 699-731.

Szokolszky, Á. (2018). Múködési zavarok és megújulási törekvések a tudományos pszichológiában, a 21. század elején. Magyar Pszichológiai Szemle, 73(4/3). 567-598. 